\title{
An Investigation of the Larval Development of Dirofilaria immitis (Leidy) in Fleas
}

\author{
By \\ EDMUND BRUNO STUEBEN
}

\begin{abstract}
A DISSERTATION PRESENTED TO THE GRADUATE COUNCIL OF THE UNIVERSITY OF FLORIDA IN PARTIAL FULFILMENT OF THE REQUIREMENTS FOR THE DEGREE OF DOCTOR OF PHILOSOPHY
\end{abstract}

UNIVERSITY OF FLORIDA

August, 1953 


\section{ACKYOWLEBEARTS}

It 1s hardiy adequate to serely acknowledge the Chalrman of mi Supervisory Cowndttee, Dr. Lewl Berner, but rather I wish to express my deep gratitude and appreciation for his guidance and ald. His sincere efforts have been a constant souree of encouragenent during the three years of ay investigation.

Ify appreclation 1s also extended to Dr. C. F. Byers for fulf1111ng the role of Chairman during Dr. Berner's entonological survey trips to Africa upon the request of the British Government.

I acknowledge special Indobtedness to: Dx. W. V. Xing, former chlef, Mr. W. C. Mebuffle, present chlef, and Mr. P. N. Mason of the United States Department of Agrieulture, Bureau of Entonology and Plant Quarantino Research Laboratery at Orlande, Florida, for supplying colonies of tleas and showing wo rearing techniques;

Dr. B. Voss, Dx. L. E. Fox, Mr. B. C. Barnes, and

Ur. F. R. Thompeon of the Department of Pharmacognosy and Pharmacology of the University of Florida for belp in surgical techniques and use of their facilities;

The many Ixiends, acqualntances, School of Pharacy, and the Gainesville Humane Soclety for allowing we to collect lleas and blood samples from doge in their care and to perform autopsios on doge destroyed becsuse of extensive injury or disease;

The College of Arts and Selences of the University of Florida 
for a Graduate Fellowship for the period of June through August 1953;

To my wlle, Gisels, for her assistance, diligence wth this manuscript, and above al1--her pationce. 


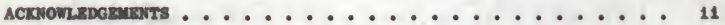

LIST OF TABLES ........................ v1

LIST OR PLATES AND EIGUERS . . . . . . . . . . . . . v11

INTRODUCTION ........................... 1

Ceneral Distribution of lloartworns in Dogs ........ 1

Beview of Theory of Nosquite Transalseton ......... 2

THS PROBLEA ....................... 5

Primary Objectives .................. 5

Secondary Object1ves ................ 5

TECHuquzs ......................

Histological Hethods ................. 7

Blood Swoars of Dogs ................. 11

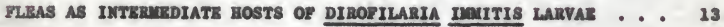

Nevlew of Literature .................. 13

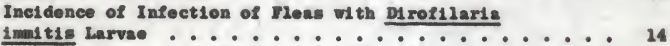

METAMORPHOSIS OF IARVA OF DIRORILARIA IUUITIS ........ 22

Method of study .................... 22

Dissection Procodure ................. 24

Description of the Wetamorphosis of the Larva

of Dirofilarie indtis ............... 25

Aberrant Behavior............... 28

BFFRCTS OF DIROFILARIA ImITIS LARVAR ON FuEAs . . . . . . 30 
TABuz of Corrants-- Continued

BEAAVIOR OF DIROFILARIA IMUITIS LARVAR . . . . . . . . 33

Act1vity of Larvae in the Flea ............. 33

lilethod of Iscape of the Larva from the Plea........ 35

Penetration of the llost by the Larva .......... 39

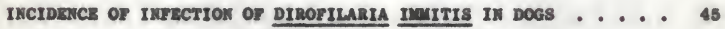

Establishing Ineldence of Infection ............ 45

Comparison of Long-hal red and short-hatred Dogs

wh thespect to Incidence of Infection .......... 49

BUIMRY AND CONCLUSIONS ................. 51

PLATES AND FIGURES ..................... 54

LITERATURS CITED .................... 65

BIOGRAPHY ............................... 69 


\section{LIST OF TABLES}

Table

1. Incidence of Infection of Dirofilaria innitis

harva in Ctenocophalldes Rel1s .......... 26

2. Position and Number of Dirof11nria ind tis

Larved in the Body of Fleas ............. 18

3. Dovelopment of Dirofilaria inat tis Isrva in Mleas ... 29

4. Tests Showl Inability of Larva to Penetrate

Intact skin ................... 42

5. Incidence of Infection of pirofilaria 1matis

In Dogs.................... 46 
LIST OF PLATES AND FIGURES

Rlate

Page

$\mathbf{I}$

Fgure 1. Prelarva of D1rofllaria 1mit1s.

Figure 2. Start of Mrat llolt of Lerva.

$\mathbf{I}$

Figure 3. Barly Sauenge Stage Larva.

Migure 4. Second stage Larva, a Distinct Sausage stage.

Figure 5. Third Stage Larva, Entering Second Molt.

Flgure 6. Infective Stage Larva.

IV Internal Anatony of a Rlen (anglttal section).....

V Sagittal Section of a rlea Showing Muscle systems and

Haomocoeles of Head, Thorax and Abdownn . . . . . .

vI Prelarva lloving Out of Midgut of a riea Into the

Haemocoele of the Abdomon .............. 60

Figure 7. Prelarvae in the Midgt of a Flea

Iigure 8. Photonl erograph of a Sausage stage Larvae in a Drop of Phyelologleal Sallne Solut1on.

Figure 9. Prelarvae lloving Out of Midgut and Sausage Stage Larvae in the Haonocoele of the Abdomon of a Ctenocephalldes canis male.

Figure 10. Fhotoni erograph of a Sausage stage Larva in the Haomocoele of the Abdomen. 


\section{LIST OF PLATES AND FIGURES-Cont1 nued}

Plate

Page

IX Third Stage Larvae lloving from the Haemocoele

of the Abdowen Inte the Heanocoele of the

Thorax of a Flea ................ 63

$x$ Serial Bection of the Ilead and louthparts of

Ctenocophel1des fells showing Part of an Infeet1ve

Stage Larva In the Vielnity of the Mouthparts ..... 64 


\section{IMTRODUCTION}

\section{General Distribution of Heartworms in Dogs}

The adult 11lariae of Dirolilaria 1matis Leidy (1856) seem to have been observed for the f1rat time during the 17 th century by Panthot (1679), Ia Peyronnie (1778) recorded simllar observations a century later. These IIndings were conlirned at the start of the 19th century by Peysson (1806), Zeviani (1809) and Bobe-lloreau (1813) and soon thereafter the worn was recorded in Europe as far north as Denmark and far south as Italy. LeIdy (1856) and schuppert (1858) noted 1 ts presence in the United States. Somorville (1875) reported that an exceptionally high incidence of infection of dogs occurred In Japan and Ch1na, whlle S1Iva Aranjo (1878) added Brazil to the growing list of countries in which the worm oceurs. Mll of these studies were based on autopay I1ndings and show that $\underline{\underline{D}}$. Ineltis infections are apparently world-wide.

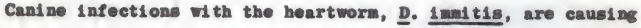
Increasing concern to dog owners throughout the Atlantic Coast states and Gulf states. Bocause of the studies of Blackbers and Ashman (1930) and HI nasen and Baker (1936), D. 1mant1s $1 \mathrm{~s}$ known to be wuch wore prevalent in the South than was commonly suspected. These authors reported that almost 50 percent of the adult dogs fron New Orleans 
are infected with heartworn.

\section{Review of Theory of Hosquito Transmission}

In most Instances, the transal ssion of the worm by any particular vector is correlated with the ability of the prelarval merollaria to develop to the infective stage. The theory of nosquito transnission of canine fllariasis has been considered so L1rily established since Grassi (1890) observed fllariae larvae in Anopheles maculipennis, which he then deternined to be developmental foras of D. 1mitis, that searches for other arthropod vectors has been largely neglected. Laboratory experimonts have dononstrated that twenty-six species of nosquitoes have been shown to be ausceptible to Infections with D. indtis. These are as lollows:

\section{Species}

Aedes aegypt1

A. canadensis

A. caspius

A. clnerius

A. excructans

A. Inflratus

A. korel cus

A. so111c1tans

A. st1mulans

A. treniorhynchus

A. triseratus

A. verans
Place or

Invest1gation

(United States)

(United States)

(Italy)

(United states)

(United states)

(United States)

(China)

(United States)

(United states)

(United states)

(United States)

(Italy)
Authority

(Fiu 1931)

(Eu 1931)

(Grassi \& Noe 1900)

(Yen 1938)

(Ph1111ps 1939)

(Sumers 1943)

(Feng 1930)

(Summers 1943)

(Yen 1938)

(Hu 1931)

(Phillips 1930)

(Grassi * Noe 1900)

*The term prelarva rofers to that stage in the life history of the worm prior to 1 ts 11 rst molt. 
Spec1es

Anopheles algeriens1s

A. bifuracatus

A. cruclans

A. $\overline{\text { hyrcanus }}$

A. hyrcanus var, stnengls

A. meul1 pennis

A. punctipennis

A. guadrinaculetus

A. superp1 ctus

Culex ratigans

c. p1piens

c. skus11*

c. tarsal1s

c. $\overline{\operatorname{terr} 1 \tan s}$
Place of

Invest1gation

(North Africa)

(Italy)

(United States)

(Italy)

(China)

(Italy)

(United states)

(United states)

(Italy)

(Ph111ppt ne Islands)

(Italy)

(Austral1a)

(United States)

(United Statea)

\section{Author1ty}

(Grass1 * Noe 1900)

(Grasel \& lioe 1900)

(Sunmers 1943)

(Grasst Hoe 1900)

(Feng 1930)

(Crassi \& Noe 1900)

(Ru 1931)

(Ph1111 ps 1939)

(Grasse1 1900)

(Del Rosar10 1936)

(Grasst \& Noe 1800)

(Baneroft 1901)

(Yon 1938)

(Hu 1931)

The species of nosquitoes chlefly responsible for transission of this disease in nature are not known.

Hinman (1935) has denonstrated that Aodes aegypt1, previously thought to be a sultable vector of the worn (Hu, 1931), Is in renlity not a compatible host. Additional work has shown that those specles of nosquitoes susceptible to the developmental stages of the heartworm larvae have a high wortality rate and cannot serve as a sultable vector. It, therefore, became apparent that some other arthropod must be $1 \mathrm{n}$ crindnated as a prime tranentter.

With the real1zation that almost all work on D. 1mit1s dealt with the parasite in the derinitive host, it beeane apparent that the effects of the worm on the Interwediate host had been relatively negleeted. Barller work had establlshed the fact that an ineect vector C. Iatirans.

Th1s specles may have been misldentifled and way actually be 
was required for the Intermediate stages of the worm and nosquitoes had been Incriminated and fleas suspected. It appeared, therefore, that an Investigation of the Iles as an intermodiate host, with partieular emphasis of the effects of the parasite on the Insect, was noeded to help complete the knowledge of this Important parasite. Wh these requi rements in mind, the present Investigation was undertaken. 
THE PROBLE

Primary Objectives

The primary objectives of this Investigation were to deternine:

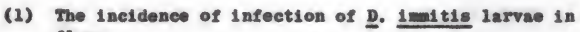
11eas.

(2) The metamorphosis of D. Inndtis larvae in Ileas.

(3) The effect of D. Imnitis larvae on the nortality rate of rleas.

(4) The elfect of D. Innitis larvae on the fertility of rleas.

(5) The behavior of D. Ineltls larvae in tleas.

\section{Secondary Objectives}

The secondary objectives were to establish:

(1) The incidence of infection of the definitive host in North Central Florida.

(2) Is any particular breed of dog more apt to have the disease than another?

The secondary objectives were a natural outgrowth of the primary ones. During ay investigation of the literature eariy in the study, I encountered conplieting statemonts with regard to the Incldence of Infections in long-halred as opposed to short-hal red 
dogs; I, therefore, became Interested in deternining whether or not there was a real correlation. Hall, Price and Wright (1934) had claimed that short-haired dogs are more susceptible to heartworms than long-halred dogs, probably because thoy have less protection from mosquito bites. Other workers such as Augustine (1936) and II nman and Baker (1936) found the highest Incidence of Infection anong lenghaired dogs. Brown (1939), having discovered slightly heavier infections in long-haired dogs, suggested that fleas and lice infested doge wore successfully when the halr was long and they should antural1y be suspected as belng intermodiate hosts of ‥ 1mitis. A brief exanination by this author of a small sample of Ctenocophalides fells showed that perhaps his supposition was correct as he found prelarvae, which he did not atteapt to identify, in several of then. The atudy began to enlarge as the correlations between the primary and secondary objectives Interdiglated unt11 it becaso rather diflicult to separate one set fron the other. I have attenpted, however, in the following discussion to make a elear distinction between the two sets. 


\section{TrCHNIQUES}

\section{Histologi cal Methods}

I resorted to sorial sectioning of lleas so thet I could accurately plot the ngration and location of both the prelarvee and developing larvae of D. Inntis In the infected Llea.

I soon found that wea I used a standard I1xat1 ve such as Bouln's followed by routine dehydration and parafin erbedding that the resultant serial sections were not satisfactory. The stained nerial sections of the fleas revenled that the amall traces of plcric acld that had not washed out interiered with the staining. The exoskeleton in almost all caees hed not been sufficlently softened for sectioning and consequently frageonted during this procedure. The shattering of the exoskeleton distorted and ripped many of the Internal structures to the extent that Identification of these beesne a problem in 1 tself.

Several of the procedures outlined in the 11 terature were tried; however, ay results were never more than lalr. Perhaps Gray (1952, p. 14) gave the best summary then he sald: No realiy satisfactory nothod for softening chitinous materials has yet been discovered. 
Insects and other chitinous forns are fixed in the fluid of Carnoy and Lobruk and are transforred wthout washing to Jurray's mixture where they remain from 12 to 34 hours. Then this mixture is washed out in chlorofore and the objects are embedded in parafin.

s11fer (1933) was very succossful in sectioning ticks using the Carnoy and Lebrun fluid as a Iixative. Although thie Iixative penotrated rapidy it was not satisfactory for lleas because it dissolved lat.

Formalln-acetic-alcohol, more familiarly known as FA, proved to be the most satisfactory fixative. Material could be left in it almost inderintely and the alcohol and acetic acld counteract each other with regard to hardening and shrinkage.

Once I1xed In FMA, the specinens were then dehydrated through the alcohol series to avold excessive distortion of the internal organs. At the sane time, since the dehydration procedure causes hardening, the Interval between changes was linally set at twenty a1 nutes.

Xylene was not satisfactory as a clearing agont. It caused the exoakeleton to become brittie. It also eaused distortion and shrinkage of the internal structures. Cedarwood oil was substituted for xylene as a clearlng agent becase it penotrated rapidiy and did not harden the tissues; however, it proved to be very diflicult to renove from the specimens when they were put in molted parafin. The traces of this non-volatile oll that usually remained ande sectioning a problen because, in spots, the ribbon was alsost "mushy" or lluid. 
9

Banzene, another clearing or doalcoholizing agent, was also

tested. It proved to be far superior to xylene as it did not harden the specinons. Chloroform was the most practieal in that it is the best selvent of parafin. However, when it was used, as in the case of using xylene and benzene, the spectmons had to be coapletely dohydrated.

Several embedding bod1a, such as parafein of varying hardnesses and welting points and celloldin, as well as double embedding were used in repeated attempts to get good serial sections.

The parafin embedding was convenient in that $1 \mathrm{t}$ was last and eerial sections were obtalned wh th ease. Howover, as heat is required and it is diflicult to deteraine the minimun amount of heat nooded for paraffin infiltration, excesafve hardening and shrinkage were a constant problew.

In order to avold henting and be confronted by the difficulty of further hardening of an already hard (unylelding) exoskeleton of the specinens, I resorted to celloldin. The use of this materis was too timo consunding and messy. As serial sections were not easily obtalned, the procedure was quickly discarded.

Inassuch as I already had a number of infected fleas belns procensed in thin cellolden, I attempted double embedding. This procedure gave slightiy better results than the parafin mothod. The Internal structures were better supported by the celloldin, and the paraftin embedding enabled wo to serial section the specinons. 
When the celloidin-impreguated specinons were heated during the paraflin embedding, the heat not only hardened the chitin but also the celloldin. A second problen developed when the tiae laterval betwoen changes of dehydrating cubstances in the cello1din process was chortened, resulting in considerable diatortion of internal structures. The slight advantage of obtalning better results by the uge of double embedding was offset by two factors. These were (1) hardenIng of both celloldin and ehltin when the paraflin embedding tine was lengthened or (2) incouplete parafin infiltration if the t1 we was shortened.

From the etandpolnts of time, convenience, and results I lelt that the paraflin embedding would be adequate if its aelting polnt were lowered and Its 11 ramess Increased for thick sectioning. One part of bayberry wax to ten parts of parafin (tissueaste $58^{\circ} \mathrm{C}$ ) was used. The resultant embedding wax had a lower molting polnt $\left(52^{\circ}\right.$ C.), and increased 21rmness. Furthermore, the nddition of bayberry wax removed the oceaslonal problen of erystallization in the paraflin when eooling.

Once the bayberry paraffin technique was developed, it was used exclusively in preparing opecimeng for sectioning. After belng satisfacterily enbedded, the fleas were sectioned on a rotary mierotome with a new razor blade used for each insect. Section wore cut at 20 widerons as only gross appearance of the organs was of inportance. 
Blood Smears of Dogs

In the early stage of the Investigation to I1 nd prelarvae I checked the blood of dogs using the technique deseribed by Phillips (1939). This method Involves the making of a tiny Inela1on on the Inner surface of the ear and then placing a large drop of blood obtalned from the cut on a glass slide. A cover al1p 18 thon placed on the drop and the blood imediately examined with 410 magnification.

On sour oceaslons autopsies showed adult fllarise where the smeare vere nogative. The adult 11lariae in these four exceptlons were exaninod. In each case both nale and female 11lariae vere prosent. The adult fenale I1lariae taken from the deg's beart were 1 mediately cut into segments about eight millimeters long. These parts were then placed in a petri dish contalning physlological sal1 ae and exand ned under a dissecting meroscope with 120 magnif1cation. As the contents of each eegnent were romoved with dissecting needles, great nubers of active prelarvae were observed. After checking Hinman's (1935) excellent paper on D. 1Eultis periodiclty, I concluded that a better technlque for sanpling blood was necessary as fert1le fenale adult s1lariae were present and periodicity not too narked.

Several techniques for obtalning blood samples, as described In varlous laboratory texts, were tried; hovever, I flnally set up ay own procedure and this proved very satisfactory.

A winiman of two ce, of blood is wthdrawn from a veln 
lecsted below the patella of the dog. This vessel is quite proilinent after the area has been shaved and can be further accentuated by applying xylene to the ekin. A hypodernie eyringe equipped wh a number 22 gauge needle proved to be the most effective in gett1ng bleod samples. The dxawn blood 1s discharged inte a emall, rubbercapped vial which previously had been rinsed with solution of heparin. If necessary, these vials can be stored for several days in a refrigerator kept at about $6^{\circ}$ C. The contents of the vials are then poured Into centrifuge tubes and centrifuged at 3600 rPI for e1ghty seconds. The supernatant 18 poured off and the concontrate spread on slides for thick smears and dyed wth Wright's staln. This technique noeded refinoment in speed and time of centrifuglng, in quantity of the sample required, and storage period. While these relinements were belng considered, Burch and Blaly (1951) published their athed which incorporated the refinenents originally lacking in ay techntque. They used two ce. samples of blood centrifuged at 4500 win for one anute, and after pouring off the supernatant exand ned the last drop. Inis resulted in a nore efficieat and satisfactory concentretion of the prelarvae. 


\title{
FLBAS AS INTEUURDIATE HOSTS OF
}

\section{Inerris Lakva:}

\author{
leview of Lterature
}

During the latter part of the 19th century wany workers in various countries, particularly Lewle (1875), Manson (1877), Grase1 (1888), and sons1no (1888) tried to I1nd the 1ntermediate host for D. Inntt1s. Sonsino (1888) reported linding some D. 1Ecit1s larvae not only in the flea (Pulex serratielps), but also in the 10use (Halmatopinus p111ferus). Grass1 (1890) and Calandruecto (1890) were not able to conf1rm sonsino's observation with regard to IInding Illarial larvae in the louse; however, they found embryonte nematodes in the lleas Pulex gerrat1c1pe and P. 1rritans and in the t1ck Rhipleephalus sleulus. The following year Grasel (1890) changed h1s opinion. He conceded that pleas and Ilee Ingest the preiarvae. The prelarvae do not undergo notenorphosis in these ectoparastes, but instead die in the intestine of the arthropods. Baneroft (1901, p. 41) exami ned Pulex serrat1c1ps, the common stablefly stonoxys, Culex vig1lax, a mosquito, and the Intestinal worm Anexlostoas. He coneluded : 
A11 these animals abstract together with blood the embryos, but the latter appear not to enter upon a metamorphosis, and after several days can no longer be traced; it is thought that they are digested.

Breinl (1921) experimented with Ctenocephalldes relis and

C. eanis. He reported that the netamorphosis of the D. imitis

larvae took place in the malpighian tubules of the lleas. Mhilips

(1939, p. 122) stated:

Eariy in the 1nvestigation 21 lleas, Ctenocephalldes canis, taken from the Russian hound /heavily infected/, were dissected and examinod for lilariae Tprelarvas and 11laria larvae/. None was infected. From these negative lindings it was apparent that lleas were not important intermediate hosts here, and further study of fleas in this connection was not ade.

Summers (1940) reported finding both prelarvae and developing 1arvae in Ctenocephalides relis and C. canis. On no occasion did he I1nd any in the malpighian tubules as reported by Breinl (1921). Bradley (1952) reported that the cat Ilea Ctenocephalides felis may be susceptible under certein conditions.

It can be seen, therefore, that there is no concurrence of oplaion with regard to the susceptibility of fleas to $\underline{\text { D. }}$ innitis or to their ability to carry the worns to the Infective stage.

\section{Incldence of Infection of rleas with \\ D. Ineitis Larvae}

Fleas were collected from 71 of the 142 dogs examinod during this Investigation. The 1203 pleas collected were removed frow both 
infected and mon-1nfeeted dogs. As I lound Ctenocephalldes fells to be the most prevalent $110 \mathrm{~s}$ on dogs in central Florida, I concentrated wy collecting, separation of sexes, and dissecting on this specles. The other genera and specles of fleas ocenslonslly found on dogs were collected and colonies malntalned in the laboratory for rearing and sdditional experiwents. The specles used were as follows:

Ctenocephalldes eanls, Xenopsy11a cheopls, Pulex 1rritans,

Behidnophaga gallinaela, and Orchopoas wekhani. The elassif1eation Is that of Fox (1940)

or the 342 male Ctonocophalldes pelis and 861 romie C. Pelis collected and diseected I Lound advanced D. Imaltis larval dovelopment in 111 males and in 335 lemales. The proponderance of somale fleas collected and subsequently dissected was due to thel $\mathbf{r}$ greater size and ease of collection. Hany male lleas were seen on the dogs Irom which specl mens were taken; however, the males proved to be nore elusive than the large, egg-1aden remales. Neaults of the collections and dissections are summarized in Table 1.

The presence of prelarvae and early larval stages was observed in more than the 446 specisens which showed advaneed stages. As I was anxious to establish the fact that the \&1ea is not a rofractory intermediate host, in which only 11mited development took place, I disregarded the earlier stages in recording positive I1ndings in this series of dissections. All the edvanced "sausage stage" Iarvae, pre-infective and infective stage larvae were found In the haemocoele of the abdomen and thorax. 
TABLE 1

INCIDEACS OF IMFECTION OP D. INTITIS LARAE II CTENOCEPHALIDËS FELIS

\begin{tabular}{|c|c|c|c|c|c|c|c|}
\hline \multirow{2}{*}{$\begin{array}{l}\text { BREFD AND CASE } \\
\text { NUYBER OF DOC } \\
\text { EXAUINED } \\
\end{array}$} & \multirow{2}{*}{$\begin{array}{l}\text { CASES } \\
\text { TLAS nOT } \\
\text { COLLELBD }\end{array}$} & \multicolumn{3}{|c|}{$\begin{array}{c}\text { NUVBER OP } \\
\text { MLEAS DISBECTED }\end{array}$} & \multicolumn{3}{|c|}{$\begin{array}{l}\text { FLEAS WITH ADVANCER } \\
\text { DEVRLOPIINT OF } \\
\text { MICROFILARIAS }\end{array}$} \\
\hline & & Hale & Fenale & Total & Male & Penale & Total \\
\hline $\begin{array}{l}\text { Shepherds } \\
6,40,52,85 \\
95,114,121 \\
\end{array}$ & 2 & 30 & 34 & 64 & 3 & 14 & 17 \\
\hline $\begin{array}{l}\text { Co111es } \\
3,5,73,104 \\
115,119,120\end{array}$ & 2 & 25 & 38 & e3 & 5 & 39 & 34 \\
\hline $\begin{array}{l}\text { Pood1es } \\
48,53,105,107\end{array}$ & 2 & 8 & 17 & 25 & .. & 4 & 4 \\
\hline $\begin{array}{l}\text { Chows } \\
50,51,87\end{array}$ & 1 & 17 & 41 & 58 & 5 & 26 & 31 \\
\hline $\begin{array}{l}\text { Cockex spaniels } \\
20-22,46,47 \\
86,116,136 \\
140,141 \\
\end{array}$ & 5 & 10 & 25 & 35 & 1 & 10 & 11 \\
\hline $\begin{array}{l}\text { Bngliah setters } \\
4,34,35,118\end{array}$ & 1 & 2 & 148 & 150 & 2 & 12 & 14 \\
\hline $\begin{array}{l}\text { Hounds } \\
1,2,18,29 \\
30-33,41,12 \\
72,74-81,89-94 \\
100-103,117 \\
134,135,130 \\
\end{array}$ & 6 & 149 & 375 & 524 & 51 & 155 & 206 \\
\hline $\begin{array}{l}\text { Dulldogs \& Boxert } \\
83,98,99,132 \\
133,137,138 \\
\end{array}$ & $\ldots$ & 26 & 22 & 48 & 11 & 14 & 25 \\
\hline $\begin{array}{l}\text { Pox Terrier: } \\
8,36-38,44 \\
45,82,88,97 \\
106,111,122 \\
\end{array}$ & 6 & 30 & 36 & 66 & 14 & 19 & 33 \\
\hline $\begin{array}{l}\text { Vongre1s } \\
7,9-17,19,39 \\
40,43,54-71 \\
84,96,108-110 \\
112,113,123-131 \\
142\end{array}$ & 40 & 45 & 105 & 150 & 19 & 52 & 71 \\
\hline $\begin{array}{l}\text { Totals } \\
\text { Pereent } \\
\text { Infection }\end{array}$ & 65 & 342 & 861 & 1203 & 111 & 335 & 446 \\
\hline
\end{tabular}


Under natural conditions, I lound that thirty-11ve percent of all the fless collected were infected with larvee in advanced stages of developnent. On several occaslons I observed fleas moving from one deg to another when the dogs were in elose contact. Thus, It appears that fleag, with their high 1ncidence of infection, act as Intermediate hosts for the dog heartworm and can readily be spread Irom one aninal to another through direct contact. Fleas may also drop from an 1 fected dog and later attach thenselves to another dog. Both wethods of transfer of the Ileas have been observed.

In order to deternine the percentage of infection of fless feeding on an Infected host I set up an experinest in which the pleas were restrleted to the back of an infected dog. After fourteen days forty of the fleas were renoved, sered, dissected, and examined for prelarval and larval forns. Thirty-elght of the lleas showed som evidence of 1nfeetion. Results of the forty disections are tabulated 1n Table 2. From this high percentage (95\%) of positives can be seen that fleas are very susceptible to infection wh th ‥ 1nmitig.

In many cases prelarvae from recent blood weals wore present as well as all stages of developing larvae ingested during preceding blood meals. The positions of the various larval stages in the body of the floe are also summarised in Table 2. 
TABLE 2

POSITION AND NO, OF LARVAB OF D. IMITIS IN THE BODY or mons ${ }^{\mathrm{a}}$

\begin{tabular}{|c|c|c|c|c|c|c|}
\hline $\begin{array}{l}\text { rusas } \\
\text { Mo. }\end{array}$ & $\begin{array}{c}\text { DIBSECTED } \\
\text { 8ex }\end{array}$ & Prelarval & $\begin{array}{c}\text { Ist } \\
\text { stege }\end{array}$ & $\begin{array}{c}\text { 2nd } \\
\text { stage }\end{array}$ & $\begin{array}{c}\text { 3rd } \\
\text { stage }\end{array}$ & $\begin{array}{c}\text { Sth } \\
\text { Stage } \\
\text { (Infective) }\end{array}$ \\
\hline 2 & Senale & $\stackrel{5}{\text { midgut }}$ & h. & h. $\stackrel{8}{\text { a. }}$ & h. ${ }^{2}$. & h. ${ }^{2}$. \\
\hline 2 & " & $\stackrel{3}{\text { vidgut }}$ & $\cdots \cdots$ & h. 2 . & $\cdots$ & $\frac{1}{\text { mouthparts }}$ \\
\hline 3 & " & $\begin{array}{c}5 \\
\text { aidgut }\end{array}$ & $\cdots$ & ... & h. 3 & h. 2 . \\
\hline 4 & male & $\begin{array}{c}39 \\
\text { nidgut }\end{array}$ & ... & •... & •.. & $\cdots \cdots$ \\
\hline 5 & female & $\cdots$ & $\cdots \cdots$ & $\cdots \cdots$ & $\bullet \cdots$ & $\cdots \cdots$ \\
\hline 6 & $"$ & $\stackrel{13}{\text { adgut }}$ & h. 5 & .... & •.. & $\cdots \cdots$ \\
\hline 7 & $n$ & ${ }^{7}$ & h. 4 & .... & h. $t$. & $\cdots \cdots$ \\
\hline 8 & ande & adgrat & •... & h. 2 & •.. & $\cdots \cdots$ \\
\hline 9 & " & $\stackrel{7}{7 \text { igut }}$ & h. 2 & h. 2 & h. 2 . & h. 2 . \\
\hline 20 & remale & $\stackrel{3}{\text { midgut }}$ & h. 2 & •... & •.. & h. ${ }^{2} t$. \\
\hline
\end{tabular}

all Ileas dissected were Ctenocephalldes fells with the exceptions of Kos. 12, 13, 14, 37, 39 and 10 which were c. canls.
b. a. - haemocoele of abdomen
h. t. - haonocoele of thorax
h. h. - haenocoele of head 
TABL: 2--Cont1 nued

\begin{tabular}{|c|c|c|c|c|c|c|}
\hline $\begin{array}{c}\text { TLEAS } \\
\text { No. }\end{array}$ & $\begin{array}{c}\text { DISSECIED } \\
\text { Bex }\end{array}$ & Prelarval & $\begin{array}{c}\text { lat } \\
\text { stage }\end{array}$ & $\begin{array}{l}\text { 2nd } \\
\text { stage }\end{array}$ & $\begin{array}{c}\text { 3rd } \\
\text { stage }\end{array}$ & $\begin{array}{c}\text { Ath } \\
\text { Stage } \\
\text { (Infective) }\end{array}$ \\
\hline 11 & Ionale & $\stackrel{11}{\text { adgut }}$ & $\bullet \cdots$ & h. 2 & h. ${ }^{2}$. & .... \\
\hline 12 & ande & $\stackrel{6}{\text { adigut }}$ & .... & $\cdots \cdots$ & @.. & $\cdots \cdots$ \\
\hline 13 & feilale & $\begin{array}{l}12 \\
\text { mdgut }\end{array}$ & $\ldots \ldots$ & h. 2 & .... & •... \\
\hline 14 & " & $\frac{1}{\text { midgut }}$ & h. 3 & $\ldots$ & h. 2 . & -... \\
\hline 15 & " & ... & $\cdots \ldots$ & h. a. & $\cdots$ & $\cdots \cdots$ \\
\hline 16 & ale & $\begin{array}{c}5 \\
\text { mi dgrat }\end{array}$ & •... & $\cdots$ & $\bullet$. & ... \\
\hline 17 & fenale & $\stackrel{2}{a 1 d g u t}$ & $\cdots \ldots$ & h. 1 & •.. & ... \\
\hline 18 & " & $\frac{5}{\text { adgut }}$ & h. 3 & s. 2 & $\bullet \cdots$ & $\cdots \cdots$ \\
\hline 19 & 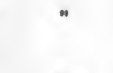 & $\cdots$ & $\ldots$ & h. & . & h. \\
\hline 20 & ande & $\frac{11}{m i d g u t}$ & h. 8 & ... & .... & $\cdots \cdots$ \\
\hline 21 & " & $\stackrel{1}{a 1 d g u t}$ & $\cdots \cdots$ & $\cdots \cdots$ & $\ldots \ldots$ & $\cdots \cdots$ \\
\hline 22 & male & $\frac{3}{\text { adgut }}$ & $\cdots \cdots$ & h. 1 & •.. & $\cdots \cdots$ \\
\hline
\end{tabular}


TABLB 2-Continuod

\begin{tabular}{|c|c|c|c|c|c|c|}
\hline $\begin{array}{l}\text { Furas } \\
\text { Mo. }\end{array}$ & $\begin{array}{c}\text { DISSECTED } \\
\text { Bex }\end{array}$ & Prelarval & $\begin{array}{c}\text { Ist } \\
\text { Stage }\end{array}$ & $\begin{array}{l}\text { 2nd } \\
\text { stage }\end{array}$ & $\begin{array}{c}\text { 3rd } \\
\text { stage }\end{array}$ & $\begin{array}{c}\text { Ath } \\
\text { 8tage } \\
\text { (Infect1ve) }\end{array}$ \\
\hline 23 & ma1e & $\stackrel{2}{\text { adgut }}$ & h. $\stackrel{5}{\text { a. }}$ & h. 2 . & h. 1 & .... \\
\hline 24 & $n$ & $\cdots$ & $\cdots \cdots$ & h. ${ }^{6}$ & h. 2 & $\cdots \cdots$ \\
\hline 25 & female & $\begin{array}{c}\text { 5ิ } \\
\text { adgut }\end{array}$ & h. a. & h. 8 & h. ${ }^{2}$. & h. 1 \\
\hline$x=$ & $n$ & $\cdots$ & $\cdots \cdots$ & •.. & $\ldots$ & ${ }_{\text {out of }}^{1}$ \\
\hline 27 & $"$ & $\cdots$ & $\cdots \cdots$ & h. 2 & h. ${ }^{2}$. & $\cdots \cdots$ \\
\hline 28 & $n$ & adgut & h. 2 & $\cdots \cdots$ & $\cdots \cdots$ & 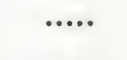 \\
\hline 29 & n & $\begin{array}{c}3 \\
\text { nderet }\end{array}$ & h. & h. 4 & h. 2 & $\begin{array}{l}\text { b. }{ }^{3}(2) \\
\text { h. t. (2) }\end{array}$ \\
\hline 30 & $n$ & $\cdots$ & $\bullet \cdots$ & $\cdots \cdots$ & $\bullet \cdots$ & •... \\
\hline 31 & $\omega$ & ... & h. a. & h. 2 . & h. ${ }^{2}$. & $\cdots \cdots$ \\
\hline 32 & nale & h. 2 & h. 11 & n. 1 & h. 2 . & .... \\
\hline 33 & " & h. 6 & $\bullet \cdots$ & $\bullet \bullet$ & $\cdots$ & $\begin{array}{l}\text { h. } 4 .(3) \\
\text { h. t. (1) }\end{array}$ \\
\hline
\end{tabular}


TABL3 2--Continued

\begin{tabular}{|c|c|c|c|c|c|c|}
\hline $\begin{array}{l}\text { TLEAS } \\
\text { No. }\end{array}$ & $\begin{array}{c}\text { DISSECTSD } \\
\text { sex }\end{array}$ & Prelarval & $\begin{array}{l}\text { Int } \\
\text { stage }\end{array}$ & $\begin{array}{c}\text { 2nd } \\
\text { stage }\end{array}$ & $\begin{array}{l}\text { 3rd } \\
\text { stage }\end{array}$ & $\begin{array}{c}\text { 4th } \\
\text { stage } \\
\text { (Inpective) }\end{array}$ \\
\hline 34 & mele & $\stackrel{1}{\text { midgut }}$ & •.. & $\cdots \cdots$ & $\cdots \cdots$ & .... \\
\hline 35 & fenale & ... & $\cdots \ldots$ & h. a. & h. ${ }^{3}$ & $\begin{array}{l}3 . \\
\text { or h. }\end{array}$ \\
\hline 96 & $n$ & $\cdots$ & $\cdots \cdots$ & h. 4 & h. 2 . & $\begin{array}{l}2 \\
\text { h. h. } \\
\text { or t. }\end{array}$ \\
\hline 37 & male & $\begin{array}{c}17 \\
\text { wderut }\end{array}$ & h. $\mathrm{s}$ & ... & h. t. & .... \\
\hline 38 & fenale & $\begin{array}{c}11 \\
\text { nidgut }\end{array}$ & h. 6 . & $\begin{array}{c}7 \\
\text { h. a. }\end{array}$ & •.. & .... \\
\hline 39 & " & $\stackrel{2}{2}$ & $\bullet \cdots$ & $\cdots \cdots$ & •.. & $\ldots \ldots$ \\
\hline 40 & " & $\begin{array}{c}31 \\
\text { midgut }\end{array}$ & $\bullet \cdots$ & $\cdots \cdots$ & h. t. $^{8}$ & or h. \\
\hline
\end{tabular}




\section{MTTMORPHOSIS OF LARVA OF D. ImaITIS}

\section{Method of study}

It was shown earlier in this invegtigation that thirty-i1ve percent of the lleas collected from dogs were lnfected with larvae or D. Inadis in advaneed stages of development.

A number of experinents were conducted so that the t1mo required for the larval atamorphosis from the prelarval form of the prelarva to the infective stage could be determined. To do this, serles of laboratory-reared, Infection-1 ree adults of Ctenocephalldes fel1s, C. canis, Xenopysile cheop1s, Bchldnophage gallinacea, Pulex 1rritans, and several Orchopeas welhand were allowed to feed on an Infected dog that, prevlous to the experiment, had been cleared or al1 ectoparasites.

During the Peeding the lleas were restricted in large test tubes and Ied through a Ine bronze sereen ( $40 \times 40 \mathrm{moch}$ per inch). The host dog was tied back dow on a rabb1t board and given a w1d anestheala. Under these conditions it was possible to have the Ileas feed for extended periods of time on the shaved abdomen of the dog. It was a simple matter to note whon the lleas wore replete by the distention of the abdomen of those which had fed. When no further 
feoding was taking place, the $210 a s$ were placed in gallon jars wich contalned a sheet of paper towelling to absorb excretory wastes. The jars were capped with 21 ne gause to prevent the 1 leas $f$ ron escaping and stored In a constant temperature and hunidity cabinet.

Young rats in restralning cages were placed in some of these Jars as a source for continued feeding. A dissection schedule was then set up for all of the pleas that had fed on the defindtive host. During the flrst six hours after taking a blood weal, samples were taken of 211 geners and species of 21 eas 1 nvolved as well as of both sexes, and these were diseected at thirty minute intervals. Durling the following six hours spectune were dissected at one hour intervals. Thereafter the remaining individuais vere dissected at twelve hour intervals.

More than 1100 1aboratory-reared fleas were dissected at set time Intervals after they had fed on an infectod host. In this way I was able to plot the time, form of the developing Iarva, and Its location in the internediate host.

Dissections earried out during the desired tine intervals required the use of twolve fless (six spectes wh a vale and fomale of each). As there were 32 scheduled periods, a total of 384 fleas was required. When the lirst of three seta of dissections was nade, more than the required 384 sleas were avallable and so were used. In repeating the experinent for the second and third tives as a check agalnst the inftiel Lindings, only the more prevalent species 
(Ctenocephalides relis, C. cants, and Xenopsylla cheopls) were reared in sufficient numbers for all of the scheduled dissections.

\section{Disection Procedure}

A flea that had fed on the infected, definitive host was IIghtly anesthetized by ether and placed in a drop of physlologieal saline solution on a slide. The suspected interwediate host was then diseected wh a series of at nute scalpels feshioned Iron No, 4 Insect pins that had been heat texpered and IInely honed.

In fleas suspected of harborlag advanced stages of larvel developwent, the mouthparts were palpated and exand ned prior to head renoval. Next the head was mevered where it jolnod the prothorax. The severed head was then woved aside in the saline. The ventrel surface of the thorax and abdonen were opened and checked for larval forms in the haonocoele. The next parts renoved were the reproductive organs after they had been earefully separated and exanined. Mnally, the complete allmontary traet was dissected out, less a whort section of the esophagus and the entire pharynx which were attached in the severed head.

The alimentary tract was earefully examined for perforations to cheel whether or not the disection was successful in preventing easy exit frow the midgut Into the haemocoele for some of the waker prelarval sorms.

The prinary dissections such as decapitation and oponing the 
abdomen were performed under a magnification of 67.5. The dissections of the organ syatems were made with a magnificetion of 112.

\section{Description of the Metanorphosis of the Larva of D. 1 mint 18}

The metamorphosis of D. Immitis prelarva in Ctenocephalldes tel1s, C. can1s, Xenopsy1la choop1s, Pulex 1 rritang, Echidnophaga gallinacea, and Orchopeas Elekhani at $27^{\circ}$ to $29^{\circ} \mathrm{C}$. Shows the typlcal norphological changes that oceur in the development of all 11 larial larvae as deseribed by Connal and Connal (1922) for Loa loa larvae 1n Chrysops allacea, Blackloek (1926) for Onchocerca volvulus larvae In S1mul1ua damnosum, and Yamada (1927) for Wuchereria bancroft1 Iarvae in Culex pipiens.

The prelarva of D. 1matt1s is aheathless form. In the course of wy dissections, I found that some of these prelarval forms had penetrated the aldgut and entered the ventral region of the abdominal haemocoele as early as one hour after having been Ingested with a blood meal by the plea (rigure 1).

Fleas disspeted two, three, four, and I1ve hours after a blood neal showed a progressive increase in the number of prelarval forms located in the haenocoele in contrast to the numbers st111 active and free in the idgut.

After having already dissected more than 300 infected $110 a s$, the earliest penetration of prelarvac into the haenoceele of the abdonen which I observed was less than one hour after the worm was Ingested. 
However, the greatest number penetrated within four to I1ve hours after belng taken in with the blood wal. On the bagis of this I1nding I concluded that in the remaining 264 required diseoctions to complete my experiment, all larval forms would be found outslde of the aldgut.

Later in the course of the experinent I found several exceptions to this conclusion. In one case an active prelarva was st111 present in the aldgut of a lemale Ctenocephalldes lel1s thirty51x hours after having been 1ngested. This appears to be a purely accidental exception. Once in the hwemocoele the prelarval form undergoes distinct changes in structure. During the flrst six hours In the abdominal eavity the Internal structures of the prelarval form, wuch as the nerve ring, excretory pore, and genltal colls becone wore obvious (FIgure 2 ).

The following twonty-four hours are the most striking in that the developlng larva appears to be compressed to two-fifths of Its prelarval length and at the same time doubles its diasoter. This phase of development varled in the different Intermodiate hosts; however, In all cases the larvae underwent thickening and shortening and developed a thin, short tal1. These 11rst-stage, stumpy larvae are 90 to 105 wierons in length and about $16 \mathrm{mierons}$ in dianeter and are found throughout the ent1re abdominal and thoracle haomoceele (Figure 3). During the second stage of development, the larva continues to thleken in diameter and starts elongating. The majority of these 
characterist1e sausage forms moasure about 240 mi erons in length and 30 microns in diaveter. The thin tall present on these forns is no longer extended as earilex but Instead shortens and is bent 11 ke a hook. The esophagus, Intestine, and anus are very distinct in these massd ve larvae. The larvae during this stage are sluggl sh and are all locallzed in the ventral region of the abdominal haesocoele. The dissections showed that the prelarvae develop into this characteristie assive "sausage stage" as early as forty-elght hours after having been Ingested by the Ilea. Seventy-two hours after the blood mal on the Infected host, only an occasional "sausage stage" larva was observed in the Infected Ileas (Mgure 4).

After seventy-two hours the third-gtage larva was equently found. This form, eceurring throughout the entire body of the llea, Is very active in contrast with the sluggish form from which it developed. In addition to 1 ts increase in length to 400 alerons to 600 mierons, the buced cavity of the larva 1 more distinct, and the esophagus is now thin, while the posterior region remalns a broad nass. Some of these early third-stage larvae st1ll retaln a reduced, hook11ke tall (rigure 5).

One hundred I1fty-six hours after the inltial blood meal, I began finding mature infective stage larvae which woasured 1600 wderons in length and more than 20 mierong in diemeter. Neter 180 hours almost all the larvae in the lleas were infective. The anjerity of the infective stage larvae vere located in 
the relatively uncrowded haemocoele of the head and thorax. However, a number were found lodged among the reproductive and excretory organs; these dislodged thenselves and moved actively in the saline when the viscera were removed from the erowded abdomen (Mgure 6).

My observations on the development of D. 1 mattis and 1 ts movements in the body of the flea are sumarised in Table 3.

\section{Aberrant Bohavior}

One of the fomale Ctenocephalides fells, dissected thirty-gix hours after the blood meal, had an active prelarva in the aldgut. At the same time several early-stage, Iarval forma were observed in the abdominal haomocoele. Apparently this prelarval fora was an old prelarva which lacked the vigor of the others ingested along with It and was unable to penetrate the gut wall. Underwood and Harwood (1938) reported maximum life span of two years, four and one-half months, for the prelarva of D. Inentis in the el reulating blood of the dog. There appears to be no information relative to the length of 11fe span of prelarvae in the gut of insects.

During another dissection, as the anesthetized female llea (Ctenocephalides telis) was belng placed in a drop of physlological sallne on a slide, the flea defocated some of the blood moal. Two active prelarvae were anong the partially digested red blood cells. This suggests that fleas may normally excrete many of the Ingested prelarvae before they have an opportunity of passing through the gut wa11. 
TABLE 3

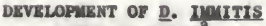
LARVA IM FLEA ${ }^{\mathrm{a}}$

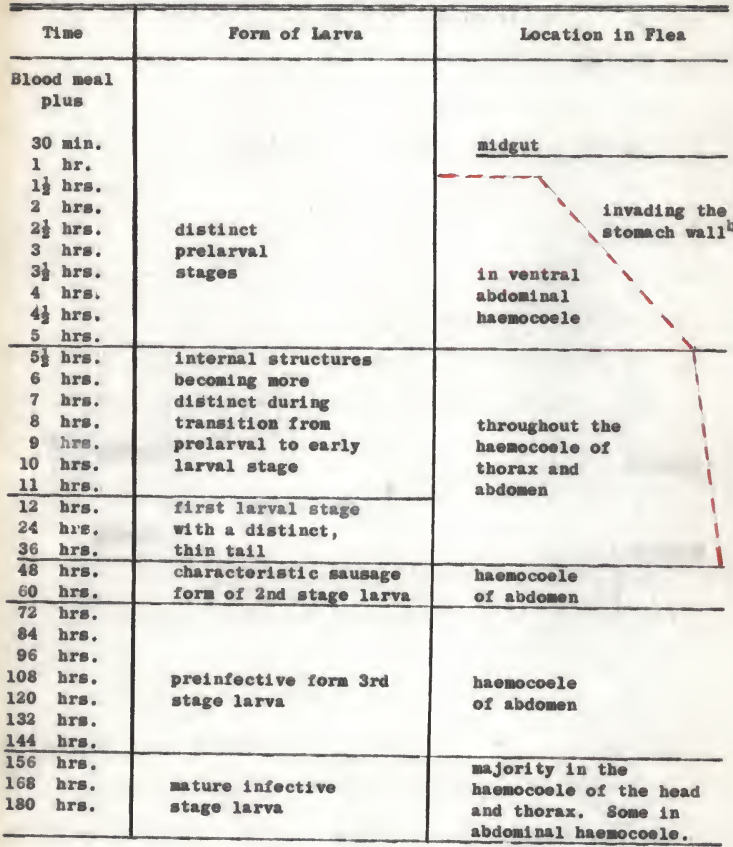

"Ctenocephalides Iells, C. can1s, Xenopsy11a cheopls, Pulex 1 rritans, Echidnophaga gallinacea, Orchopeas wi ckhad1.

botted red line indicates time of penetration of stomach wall by prelarval forms. 


\section{EFFECTS OF D. IMUITIS LARVAB ON FLBAS}

As was reported earlier (Page 3), lnosguitoes that are susceptible have a high wortality rate when they are infeeted with D. Imatis Iarvae. Unlike the larvae of other filariae such as Wucherer1s bancroft1 and $\underline{W}$. malay 1 , which motamorphose among the thoracle muscles of the mosquito, the larvae of $\underline{D}$. 1mit1s undergoes the early stages of developmont in the malpighinn tubules of the mosquito. In the course of this development the excretory organs of the nosquito are subjected to extensive danage so thet it is Improbable that they are st111 sunctional. Mortallty rates as high as 100 percent due to this damage were recorded by Bradley (1953) for some specles of nosquitoes. In 2leas, however, the early development of D. Inatis Iarvae occurs in the haemocoele rather than in an essent1el organ.

In oxder to be able to approximate the mortality rate of Infected lleas as cospared to Infection-free fleas, I used eleven colonies of sleas soparated into three experimental groups. Groups $A$ and $B$ were the colonies of Infected Sleas and Group $C$ composed of three infection-free colonies. Group A consisted of $\$ 1 x$ colonies of laboratory-roared, Infection-free fleas. They took their f1rst blood 
wal on an Infeeted dog. Subsequent feedinge by Group A were made on young rats confined in suell eages to restrict movemont. Group B consiated of two colonies of 11 eas taken from infected dogs. These were placed on young rats for further feedings. Group C, made up of three laboratory-reared, Infection-1roe colonies used as a control, fed exclusively on young rats. In each of the eleven colonies composing Groups A, B, and C twolve wale and twolve fenele fleas wore kept on ectoparasite-free, young rats.

Observations on anesthotized fleas and sanple diseection of other fleas from Groups A and B were asde and thelr Infections verified by discovering the presence of developing larvae of $\underline{\text { D. }}$ indtis. Dally observations asde over a twonty-day period showed no difference as to mortallty rate of the Infected Ileas of Groups A and B as compared to the Infection-free fleas of ay control Group C.

I noted the presence of flea egge in as great nuibers in Groups A and B as in Group C. Connts of llea eges present in all the eleven colontes were not aade becaues of two factors: (1) the question of viability of the eggs, and (2) the t1ae required for an accurate count of the enormous number produced. The problem that was presented was solved rather siaply. I nerely waited uat11 the egge hatehed and the flea larval went into the pupal stage. After sifting the pupae out of the sand and debris in the rearing eages, I neasured their velumes in a graduate cylinder. The volumes of pupae of the control Group $\mathrm{C}$ were not larger than the volums of pupae whlch were the 
offspring of the infected colonies comprising Groups A and B. The pupse of all colonies were kept for adult emergence; here agaln there was no apparent difference as to numbers of adults.

The results of these experiments elearly show that there is no Increase in the mortality rate nor apparent effect on the fecundity of the female fleas or fertility of the male fleas harborlag an Infection of D. Inatits larvae. 


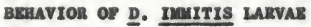

Activity of Larvae in the Hea

As was mentioned earlier in the discussion of larval

netasorphosis (Pages 27 and 28), the majority of the infective stage larvae were found in the haenocoele of the head and thorax of the d1 asected infected lleas. These infective stage larvae, because of their high degree of wotility, were able to move against the haemoIyaph flow and leave the crowded, organ-packed haemoooele of the abdonon.

In order to observe the novements of the Infective stage larvae in the living llea, I tried several restraining wodia such as polyvinyl alcohol and methyl cellulose. These were not effective in restricting the movements of the active lles; therefore, I employed ether to anesthetize the insects.

The IIghtly anesthetized flea was then placed on a glass sllde and the internal regions of the head, thorax, and abdomen were observed with the ald of a 100 and 440 magnification. In each case a strong bean of transaltted light rather than reflected light was used as a light source.

In almost all cases the activity of the worn larvae could be 
observed in the Rlea. The greatest difficulty was encountered when some of the larvae moved 1nto the abdominal haemocoele. The erowded organs wore seen belng pushed about in the lightly chitlalsed Xenoprsila cheopls as the active Iarvae noved among them. The larvae were vistble at times; however, when they stopped theix novement it was inpossible to distinguish them from the internal organs of the 11ea.

The movement of the larvae in the haemocoele of the thorax and abdomen can best be deseribed as belng that of a typleal nomatode. In the haonocoele of the head, however, they displayed nore of a gliding action with a nimuin of lateral motion. I began to speculate as to why the activity in the haemocoele of the head was such a contrast to the rather violent notion exhibited in the thorax and abdomen. Then I noticed that one of the larvae that had apparentiy penetrated, in part, the minute haenocoele of the Iabrun suddenly wove backwards. The gliding novenont exhlbited by the larve in the haemocoele of the head was the result of the restricted area for noveront.

I was able to Induce the backward movement of the larva from the head into the thorax by gently applying an 100 cold blunt disseeting pin to the wouthparts of the llea. In other tests, I put a drep of sallne over the mouthparts of the anesthet1sed 210 and shortly thereafter could observe the forward movement of the larvec wriggling in the abdomen, subdued activity in the thorax, and then the 
restrieted movement into the head.

Method of Bseape of the Larva from the Flea

The wechanisa of the escepe of the 1nfect1ve stage larve from the Intermedlate to the definitive host follows a very intricate pattern. The f1rst requirement is that the fully developed larva be lecated in the vielnity of the mouthparts.

Ilonon and Ramamurt1 (1941), In the1r Invost1gation of Wucherer1a bancroft1 larvae, found that with moderate warmth (about $35^{\circ}$ c.) the Infective larvae became very active and could be observed moving to the very tip of the probosels of infected culex fatigans. They suggested that warmth was a def1nite factor in larval escape since 1t brought about increased activity.

$4 y$ experiment with the Infective stage larvae of $\underline{D}$. 1ant1s In vaxlous infected lleas also showed a sinllax pattern of larval concentration in the head region when warm physiologleal saline was placed on the nouthparts of the 1les.

After having succesded in concentrating the larvas in the haenocoele of the head, I tried a series of stimull to Induce then to leave the body by moving out of the mouthparts. My 11rst test involved use of hot sal1ne $\left(45^{\circ}-52^{\circ}\right.$ C. $)$ around the wouthparts. With this, those that did not die in place rapldiy noved back Into the haewocoele of the thorax and abdonen. Cool sal1ne $\left(22^{\circ}-24^{\circ} \mathrm{C}.\right)$ did not k111 any of the larvae; however, all left the near vielnity of the 
head and withdrew inte the body.

Warm lyaph and later warn blood Increased the activity of the larvae in that they moved from the haemocoele of the abdomen and therax into the haemocoele of the head. However, this Increased activity was no greater than that brought about by using the warm saline. The results of the teat with cold lymph and cold blood wore the same as those with the cold saline.

These sinple tests showed that the chemical stimulus was 1ncidental. The prinary stimulus proved to be the presence of a warn lluid over the mouthperts, for this alone lncreased the concentration and activity of the larvae in the haemoeoele of the head. No oscape of the Infective stage Iarva was seen after the exteran applicstion of warn lluids to the nouthparts.

I realized that I could not duplicate the position of the wouthparts of the anoathetized flea to that of a Ilea setively foeding. Thereupon I tried to $11 x$ an Infected flea in the act of feeding on a host. If plans wero to serial section the foeding flea and the excised skin of the hoet, and thus be able to deternine the way Infeetive D. Inaftis Isrvae enter the defindtive host.

The standard I1xatives such as Bouln's, the aleohols, formiln comblnations, Lo Blaneo's IluId, and Gison's fluid all aetod too slowy in that the leeding llea released its mouthparte imadiately. The anesthosias such as the ethors, chloroform, ethyl chlorlde, and carbon dioxide wero not satisfactory as the flea shifted almost 
inmediately after exposure to these substances. The comberel al insectlcldes were all too slow. Contact freesing with dry 1 ce proved to be too awkward. As a last resort I held a shell vial that was partially I11ed with cotton saturated with a four percent osule acid alution over a feeding Ilea. Contrary to all expectat1ons, the Ilea was st111 slive ton winutes lator! Noedless to say, this experiment was abandoned.

The flea, 1n preperation for taking a blood meal, f1rst anke a prelindnary investigation of the skin with the maxd11ary palps. Then the head 1s applied to the skin, the abdomen being hold at an angle of about $45^{\circ}$. The lablal palps are widely apread and the mandibles, the only plercing appendages, are thrust 1 ate the skin. The resultant would is caused by the protraction and retraction movement of the adibles. Saliva is poured into the would during this action. The skin of the animal bolng bitton, due to the saliva of the llea, 1s, at times, severely Irritated. The blood wh thawn from the host moves up the rood channel 1nto the pharyax, down the esophagus, through the proventriculus, inte the addgut. The distention of the migut l1111ng with the blood meal fron the host brings about a rise in the intra-coelonde pressure of the llea. This rise of the Intra-colonic pressure stretches the intersegmental membranos connecting the exoskeleton and thus may somet1mes pervit larval escape through the body wall.

I aseumod that the easiest location for exit of the larveo would 
be In the region of the wouthparts. The labrun-epipharyax, which has been described as the labrun and also the opipharynx by Fatton (1913), is a long, slender organ, flattenod on Its ventral surface where it is In opposition to the mandibles (P1ate X). The dorsel wall, correspondIng to the epipharynx, are composed of rigld chit1n, whereas the lateral walls which connoct these structures are nowbranous. Within these walls Is a space cont1 nuous with the haemocoele of the head. At times I had observed larvae in the vicindty of this strueture. The Iablun (proboscls) of the flea is the nost posterior of the nouthparts. It consists of a short, modian, basal, hollowed-out, thin, chit1nous plate with two, four-segmented, lablal palpa, or 1abel1a, at its distal end. As nentioned earlier, the labial paips do not enter the wound, but are bent to the right and left as the anndibles enter the skin.

As with the labrum, I observed Infective stage Iarvae in the vielnity of the Iabiub and what appeared to be a partial entry into its haenoceele. During the course of this phase of the investigation I had 14 eases where palpation of the nouthparts, whlle Iunersed in warm physlological saline with pressure applied at the same timo to the distended abdomon, resulted in the emergence of infective stage Iarvae from mouthparts of the flea. I was unable to determine which of these short struetures was the principal exit polnt.

On nany other occasions when an engorged flea contalning Infective stage larvae was Injured in any way by Impropor handilng, it 
was not unusual to have the infective stage larvee emerge by way of the injured areas.

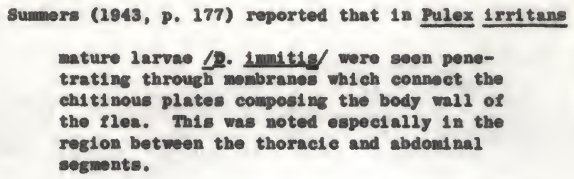

Penetration of the Host by the Larva

Nany of the present day texts have statewents 11 ke this:

They /1nfective Iarvee of l11aria/ are not di rectly 1 soculated by the bite Zreferring to a blood feeding arthropod/ but pierce the skin, enter the elreulation... (Stitt, Clough and Clough (1945, p. 513)

I assuned such statements, as the quotation above, to be true, but when I examined serial sectione of ok1n which had been plerced by arthropods infected wth several infective stage larvae, ay findings wre wager. Serial sections made of skin upon which an injured Plea that had infective stage larvae enorglng 1 row 1 t showed no evidence of larval penetration.

I realized that I know nothing as to the speed of penetration and where the larvae noved once thoy had entered the definitive host. Therefore, I declded to try to count the number of infective stage larvae in the llea before and after a blood meal. This, of course, was not accurate. However, by gross examination, as prevlously deacribed, I was able to estinate whether or not one or wore infoctive 
stage larvae wore present. In this experiment I used only lleas in Which infective stage larvae could be seen. The skin of a new-born rat, In the region of the bite ade by the interwediate host, was removed, 11xed, sectloned, stalned, and checked for the presence and number of 1 afeetive larvae. The flea that had taken the blood moal was dissected in phyolologleal saline and examined for the presence and number of Infeet1ve stage larvae.

The anjority of the bkin samples that were serially sectioned d1d not show the presence of the larvae. However, an occaslonal portion of a penetrating larva was found in fow samples of skin. At the same t1me, the Infected fleas, both the Injured from which larvae were observed exlt1ng onto the skin of the host and the uninjured which I assumed could discharge larvae through the mouthparts, showed a frequent decrease or complete absence of all previously observed Infect1ve stage Iarvae.

In the ceurse of this experinent I observed forty-seven infective stage larvae in twenty-oight infected lleas; the number of larvae was, in all probabilities, higher. The okln sanples gave three positives, and in the dissections of the twonty-elght lleas I found seventeen remalning larvae.

Probably more than the twenty-seven infective stage larvae were not accounted for. I began to doubt the statenent that larvae penetrate the skin and therefore set up a series of experinents in order to determine whether this was true or not. 
A serles of infected Lleas, Ctenocephalides fel1s, C. canis Xenopys11a cheoplas, and a mosquito, Psorphora ferox, were dissected in sall ae as a source for 1nfective stage larvae. The larvae were then recovered in aifero-plpettes and placed on various types of intact skdi in a drop of saline or lymph and observed through a dissecting nileroscope. The results of this experinent are sumarised in Table 4.

The reaults of placing larvae on 1ntact skin showed that they were Ineapable of penetrating 1t. The larvae noved about actively In the droplet of saline. When the1r molst mediue began to evaporate, the1r aovements became more restrictod. By the timo the drop had cosapletely evaporated, the larvae dried up and died.

The next test used shin that had been broken. I employed Insect pins, dissecting neodles, and a sharp pointed scalpel to simulate the punctures that an actively feeding fles makes. I real1zed that the openings lacked the anticoagulin that the foeding Plea pours into the wound wh 1 ts sallva. I tried heparin $(1: 9000)$ and also sallne; however, this added to the difflculty of tenperature regulation, dropping it to weh a polat that the larvae, sonsitive to slight temperature changes and positively thermotrople, would not move toward the wound. Because of these factors and ropested fallures, the addition of diluting agents and anticoagulants was discontinued. When the larvae were dropped over the puncture in the skin, penetration into it was rapld. The larvae that were near the 
TABLE 4

TESTS SHOWING IMABILITY OF LARVA

TO PENETRATR INTACT SEIN

\begin{tabular}{|c|c|c|c|c|c|c|}
\hline $\begin{array}{l}\text { No. of } \\
\text { Larvae }\end{array}$ & Intact Skin & & $\begin{array}{c}\text { Time } \\
\text { Interval }\end{array}$ & & Reaults & \\
\hline 6 & Shaved leg of a dog & $\mathbf{1}$ & $-15 \mathrm{~min}$. & no & peaetration, & died* \\
\hline 9 & Back of a young rat & 1 & - $15 \mathrm{~min}$. & $n$ & $n$ & $n$ \\
\hline 3 & Belly of a young rat & 1 & - $15 \mathrm{~min}$ & $n$ & $n$ & $"$ \\
\hline 4 & Bar of a dog & 1 & $-15 \mathrm{~min}$ & $n$ & $\mathbf{w}$ & $n$ \\
\hline 2 & Finger of a man & 1 & $-15 \mathrm{~min}$. & $n$ & $n$ & $\omega$ \\
\hline
\end{tabular}

-Died because of desiccetion. 
edges of the puncture nerely wrigeled back and forth unt1 1 they dried up.

I belleve that when the Infective stage Iarvae escape from the feeding Ilea, whether through the mouthparts or through the broken body wall eaused by the crushlng of the flea by the host, they w111 penetrate the host under these conditions:

1. If thoy onorge frow the elea Into a molst modium that prevents their dehydration.

2. If there 1s warn blood and tiswe fluid exuding frow the wound (beceuse of the injected sallva containing an ant1 congulant).

3. If the distance between the location of the Iarvae and the wound is bridged with a nolst moditum.

4. If the distance between the larva and the wound is very short-less than two ndilanters.

Bre1nl (1921, p. 391) stated:

The wode of transul ssion was coneldered, and It was thought possible that under normal conditions the llea would be crushed, and the actively mot1le larvae thus frood would ponotrate through the unbroken skin and reach the blood strean In analogy with the vochanimen of Ancrlostone infection.

In order to ascertaln the correctness of the surmice, fleas were erubhed over the shaved skin of younc pupples which had been molstened with saline, and after an Interval of from flve to twenty minutes the part of the skin was exclsed and serial sections prepared for mi eroscopleal exanination

In one Instance only out of seven experiments one mature larva was discovered in threo consecut1ve serial sections with the anterior part (about 30 inicrons of the larva) embedded in 
the subcutaneous tisaue, the remaining part adhering to the outer skin. The lerva had, whout doubt, penetrated through the unbroken skin.

Considering the fact that the exoskeleton of some fleas is thick and brittle, I belleve that when these were Impressed on the tender skin it produced some breaks in the shaved akin and this gave partial entry for one larva. 


\section{IMCIDENCS of IMYgCTION of D. Imitrs IN DOCS}

\section{Batablishing Incldence of Infection}

One hundred and forty-two does were exanined during this Investigation. They runged from approximately four months through twelve years of age. When a dog was exanined, it was given a case number and the following data were recorded on work sheets:

1. The breed of the dog.

2. Whether it was long-halred or short-hal red.

3. Age (actual or approximate).

4. Results of blood smear made fron blood sanple taken.

5. Mesults of the autopsy 11 the dog was destroyed for reasons montioned earlier (Page II).

6. Pesults of the number of pleas that had been sexed and dissected (Table 1).

Items 1 - 5 are sunmarized in Table 5.

Of the 142 dogs exanined, 89 had positive blood snars showl ng the presence of prelarvae. Since the time of development of the Infective stage larve to the adult Plaria was estiated by Iall, Price and Wright (1934) as being a 11ttle over eight wonths, all dogs leas than eight nonths of age theoret1eally should have beon subtracted from the total number of doge examl ned for prelarvae of D. 1mitis. 
TABUB 5

INCIDENCS OP IXmCTION of D. InItrs IN Docs

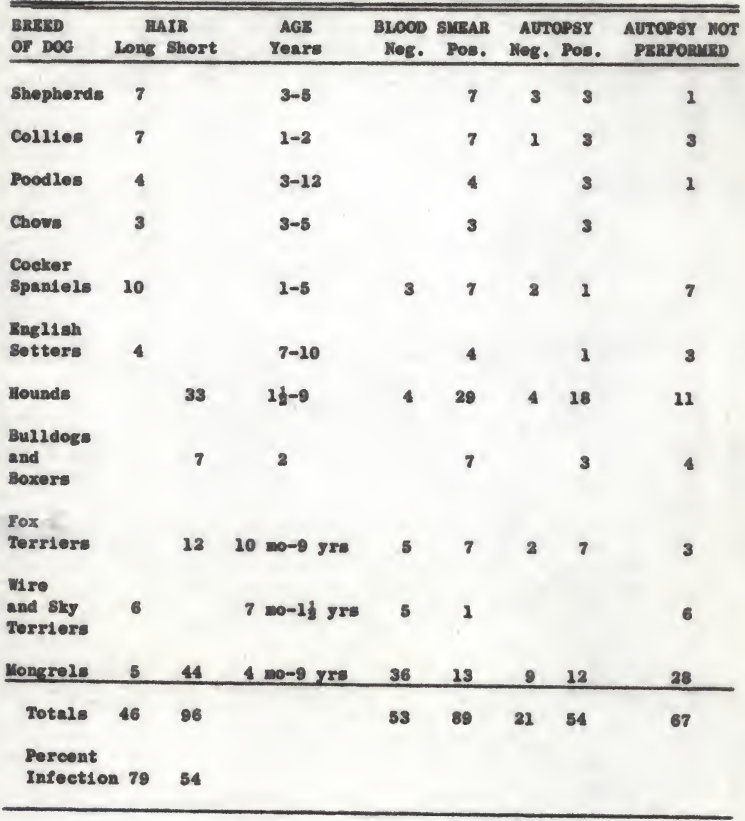


The percentage of the incidence of infection would rise from 63 percent to 77 percent 11 the 28 dogs less than eight months of age were subtracted from the total number exandned. However, I Ineluded these dogs because two of then, known to be less than soven months of age, were found to have prelarvae in thelx blood samples. Furthermore, Augustine (1938, p. 393) reported two I1ve months old cocker spaniel pupples as belng infected. Ilo stated:

The exanination of the nother's bleod was negative for mierofilarise. If prenatal infection did not occur, the sbsence of the lnfection in the mother may indicate a decided preference of the 1 nfective stage of the parasite $\mathrm{from}$ the mosquito for letal tissue, such as 1 s know to be true of the infective stages of an ascarid (Toxocara canis) and hookworn (Ancylostona cani num) in prenatal infections in dogs. (Augustine, 1927; Foster, 1932).

I perforned sutopsies on 75 of the 142 dogs exant ned. The autopsies wre perforned on dogs that had been destroyed because of extonsive 1njurles or disease. The following organs, which ulght be involved, were exanined in this sequence for adult s1lariae.

1. the four chambers of the heart

2. postcaval vela (1nferior vena cava)

3. pulmonary arteries

4. lunge

5. thoracle cavity

6. diaphragn

7. nesentery

The adult lliariae of D. Innitis wore usually found in both the right auriele and right ventriele. In severe cases an appreciable number were found 1a the pulmonary artery, and sone in the lungs. The majerity of the autopsies revealed about twelve to elghteen present. 
In one case I found 100 adult f1lariae in the heart and thirteen in the pulwonary arterles. Ilognin (1883) reported several hundred adult lilariae present in the heart of on infeeted dog.

The worms, When preeent in great numbers, were Interlaced In an almost inextricable way into huge masses wh ch, to some extent, obstructed the cavities of the heart. The fllariae wore partially wound around the chordae tendinge for attachmont, and unattached enda of their bodies hung in the lumon of the heart.

In fifty-four autopsies I found adult fllariao; however, in four of these doge the blood smears showed no evidence of prelarvae. The adult male and fomale lilariae were present in each of these four exceptions. Dissection of the feale filariae revended that they wre fert110. Fortunately these autopsies were performed during the early stage of ay investigation and omphasized the need of a wore accurate wethod of preparins blood spears. The nothod of disecetion of the fllariae and preparation of blood enears are deseribed on Page 11.

later in the etudy examples were found in which the blood smoars were positive but no adult fllarine were found. As stated earlier (Page 28), Underwood and Harwood (1939) reported the maximam 11fe span of the mierofilariae of D. immitis as belne two years four and one-half wonths in the elreulating blood of an infected dog. Whon eight cases of Infection showed the presence of prelarvae and a thorough autopsy revealed no fllariae, I assumed that they had died 
and subsequently fragnented. Leldy (1881), on two occasions, witnesed the sctual vomiting out of IIving f1lariae. These f1larise probably had been dislodged from the right side of the heart and were trangported through the pulmonary arteries to the lungs $\mathrm{from}$ which they were discharged after severe 1 tta of eoughing.

Conpartson of Long-halred and Short-hatred Dogs wh thespect to Ineldence of Infection

of the dogs examinod in the course of this investigation, 46 were long-halred and 96 short-halred. These 142 dogs represented twelve distinet breeds while 49 were non-descript mongrels.

Opon examination of blood smears, I discovered that, of the 46 long-halred dogs exant ned, 37 of then (79 percent) were positive wh prelarvae present. Among the 96 short-ha1red dogs I found 52 dogs (B4 percent) Infected. Autopey l1adings on specle1e cases showed no differenee between long-halred and short-halred doge as to the Intensity of adult I1larial infection. These I1ndings were not In agreenont with thos of Hall, Price and Wright (1934) as nent1oned en Page 6.

The breed of the dog appears to heve no influence whatsoever on susceptibility to B. 1mitis. Th1s conclusion $1 \mathrm{~s}$ based on the study ol ninety-three dogs which lell into twelve distinet breeds showing markod resistaneo to infection.

In the cases where autopsies were performod, agaln there was no visible difference as to the intensity of adult I1larial infection. 
The small number of nongrels infected is not an indication of resistance to D. 1 maltis, but rather due to the fact that tweaty-aix of the number exandned were pupples botween the ages of four to ten months. Theis blood smears wore all negative probably because they had not been exposed to prenatal infection. 


\section{SUMURI AND CONCLUSIONS}

A study of the relationghips existing between the dog heartworm, Dirofllarla 1mitis, and various species of lleas was undertaken is order to deterad ne the effects of the parasite on a potential interwediate host. The findings and conclusions resulting from this study are aummarised below:

1. Thirty-11ve percent of 1203 Ctenocephal1des fells, collected from eoventy-one doge were found to be infected with D. Imatig Iarvae in advanced stages of developront.

2. When speot mens of Ctenocephalldes Relis and C. eanis wore restricted to feeding on an Infected dog, ninety-elght pereent of then becam Infected wth ‥ Ineit1s.

3. The development of D. Inltis alerofilariae to the infective stage was traced in both anles and fenales of Ctenocephalldes fells, C. canle, Ionopgy 11a choop1s. Pulex 1 rritang, Echidnophage gallinaces, and Orchopons wlokhani.

4. The prelarval forns of D. Imuitis penetrated the aldgut wall and entered the abdominal haonocoele of the llea as early as one hour after having been ingested wth a blood weal.

5. The f1rut and second stages of development of D. 1 mintels 
Iarvae take place in the haemoeoele of the abdomen.

6. The third-stage larvae were found in the haenocole of the abdonon and thorax.

7. The majority of the infective stage larvae were found in the haenocoele of the head and thorax.

8. Floss way egest atcropilariae when partially digested blood moals are defecated.

9. Disections and serial sections of infeeted fless showed that no anjor tissue damage or apparent Injury of any organs could be attributed to the developing larveo.

10. The fortility of the ale floas wa not affected in any way by the developing larvae, nor was the egg production of the fomale Ileas changed by the larve infecting then.

11. There was no apparent 1nerease in the mortality rate of lafected fleas as compared to the wortality rate of non-infected fleas.

12. The infective stage larvae were shown to be thernotrople concentrating in the haonocoele of the head of the flea when warm sal1ne was placed on 1 ts mouthparts.

13. The Infoctive stage larvae are apparently ineapable of moving out of an unfed rlea.

14. In fourtoen cases infective stage larvae escaped through the region of the mouthparte of Ied fleas wen the intracoelonic preasure of the flea was increased.

15. Infective stage larve were observed leaving the body of 
the slen through injured areas of 1 ts exoskeleton.

16. Infective stage larvae proved to be ineapable of penetrating intact skin.

17. Prior to feeding, approximately forty-seven infective stage larvae were obserwed in twenty-eight infected pleas. After leeding, the lleas were dissected and revealed only seventeen realniag infective stage larvae. Sk1n ganples taken from the areas bitten by the lleas showed the presence of three D. Imatis larvae in the punctures caused by the feeding of the lleas. Thls denonstrates that infeetive stage larve are eapable of leaving the llea and entering the skin puneture ade by $1 t$.

18. sixty-three percent of 142 dogs examined had positive blood smears showlig the presence of mierofilariae of D. 1mattis. 19. There was no evidence in dogs of breed resietance to D. Initis, nor was the intensity of infeetion dependent on whether a dog was loag-haired or short-hasred.

20. Because of the high percentage of infected lleas sound under natural conditions, and because of the close sssociation between dogs and Ileas, these Insects are wost likely the natural vectore of canino L1Lariasis. 
PLATES AND FIGUars 


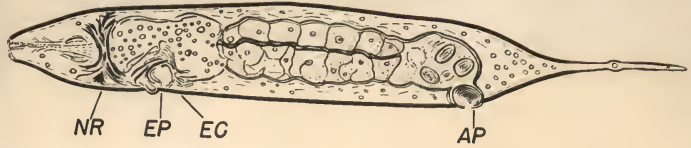

FIGURE 3

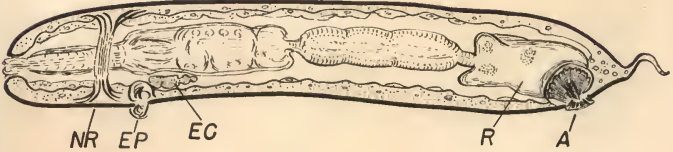

FGURE

4

Figure 3. Iarly sausage stage larva (105 wierons long and 16 mi erons d1ameter).

Figure 4. Second stage larva, a distinet sausage stage (240 mi erons long and $30 \mathrm{wi}$ erons diameter).

Abbreviatlons

A, anus; BC, exeretory cell; EP, exeretory pore; MR, norve ring;

R, rectum. 


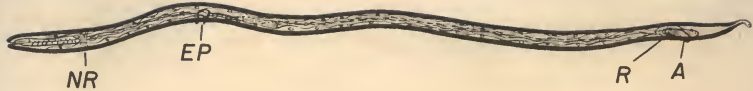

\section{FIGURE 5}

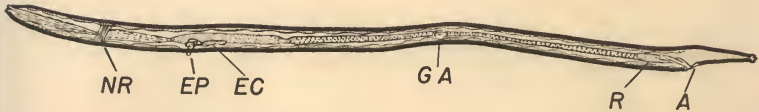

FIGURE 6

Figure 5. Third stage larva, entering second nolt (600 mi erons long and about 20 mi erons dianeter).

Figure 6. Infective stage larva (1600 microns long and 20 mi erons diameter).

\section{Abbreviations}

A, anus; $B C$, excrotory Cell; EP, excretory pore; CA, genital anlage; NR, nerve ring; $B$, rectui. 

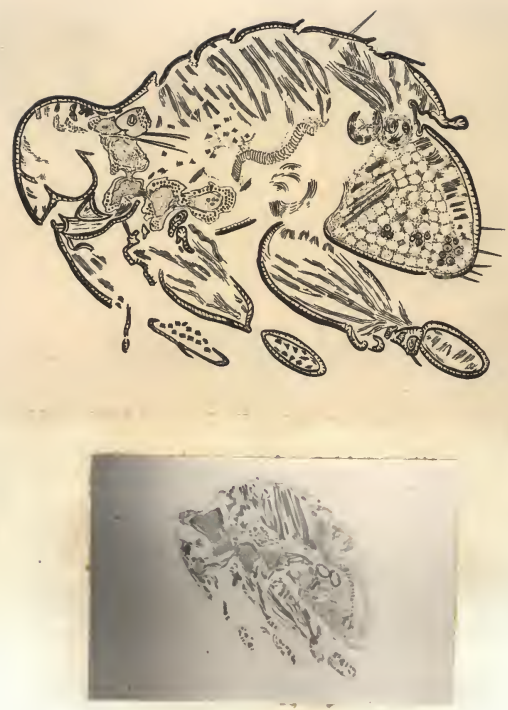

Sagittul section of a Rles showlig muscle systems and haevocoeles of head, thorax and abdomen. Notice fat body eells in posterior region of abdomen. 


\section{PLATE VI}
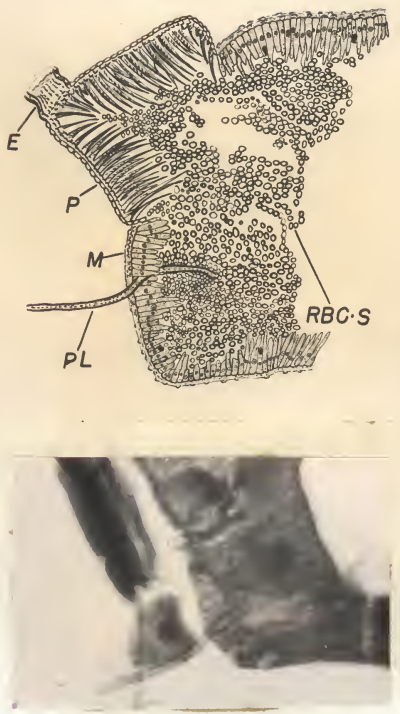

Prelarva woving out of aldgut of a flea into the haenoeoele of the abdomen.

\section{Abbreviations}

B, esophagus; $U$, midgut; $P$, proventriculus; $R$, prelarva; RBC.8, blood neal. 


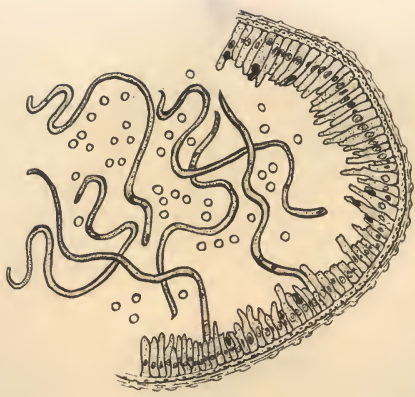

Figure 7

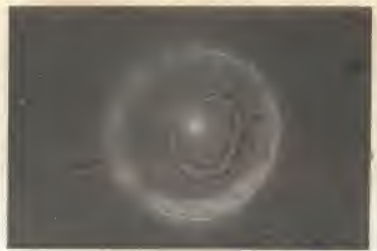

Higure 8

Fgure 7. Prelarvae in the midgut of a llea.

Fgure 8. Photomlerograph of a sausage stage larvae in a drop of physiological saline wolution. 


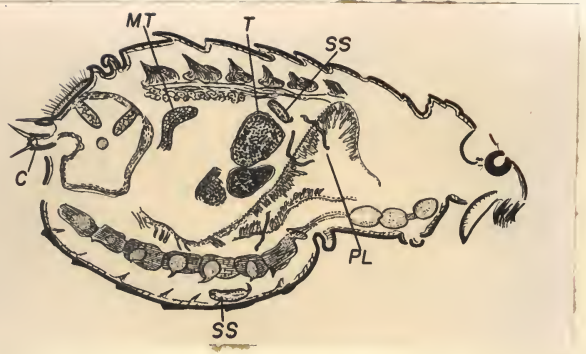

Heraxe 9

PIgure 10

Pigure 9. Prelarvae moving out of uidgut and sausage stage larvae in the haemocoele of the abdowon of a Ctenocephalldes canss male.

Tgure 10. Photonderograph of a asusage atage larva in the haenocoele of the abdomen (saline dissection).

Abbreviations C, clasper; $\mathrm{MT}$, andplghian tubules; $\mathrm{PL}$, prelarva; 88 , sausage stage
larva; $\mathrm{T}$, testes. 

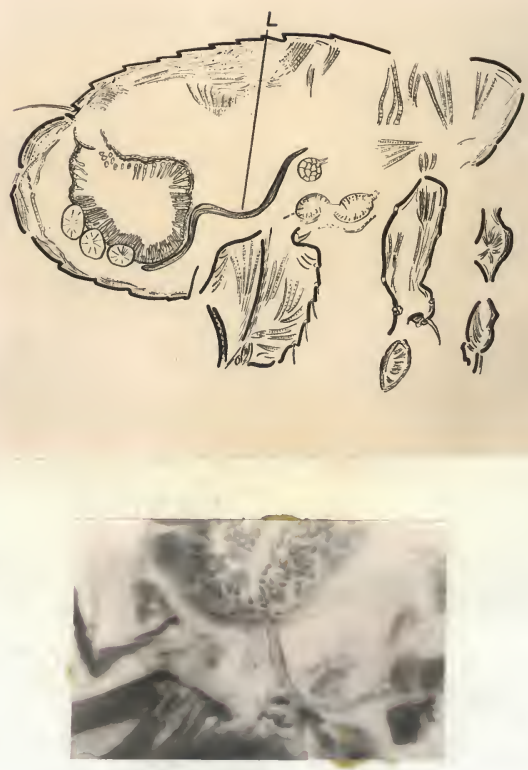

Third stage larvae (L) woving from the haenoceole of the abdomen into the haomocoele of the thorax of a flea. 


\section{PIATI $\boldsymbol{X}$}
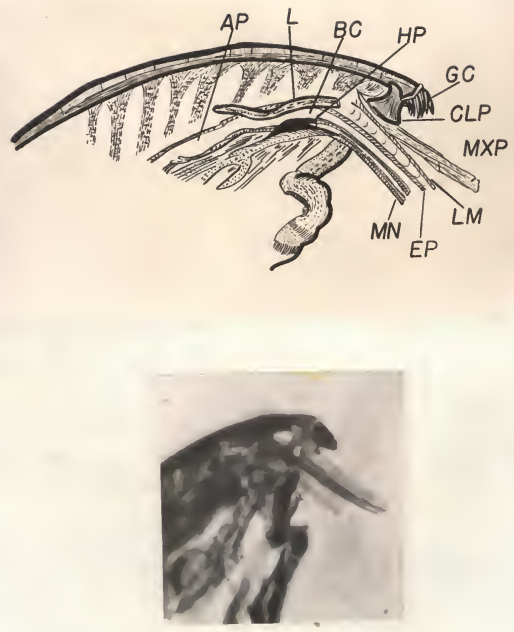

Serial section of the heed and wouthparts of Ctenocephalides fells chowling part of an Infeetive stage larve in the vicinity of the mouthparts.

\section{Abbreviatione}

AP, amplratory pharynx; BC, buceal eavity; CLP, clypens; EP, ep1pharynx; GC, geanl comb; HP, hypopharynx; L, Infective stage larva; L, labrum; $12 N$, madibles; ux, andilary palps. 


\section{LITERATURE CITED}

August1 ne, D. L. 1938. Observations on the occurrence of hoartworns Dirofllarla inad 1s (Le1dy, 1856) in Nev England dogs. Aner. Jour. HyE., 28 (3): 390-395.

Baneroft, T. L. 1901 Prelininary notes on the intermediary host of Fllaria 1 mitis, Leldy. Jour. \& Proc, Royal sos. of NeV s. Walss, (35): $11-48$.

Blacklock, D. B. 1926. The development of Onchocerca velvulus In S1mul1 un damnosum. Ann. Trop. Hed., 20: 1-48.

Blackberg, 8. N. and R. Ashman, 1930. Jour. Aner. Vet. Kod. Assoc., LxxVII: 204-212.

Bobe-Moreau, A. 1813, Jour. Gen de Med. de Sed111ot, xLVII: 3.

Brad1ey, R. B. 1952. Observation on the development of Dirofilaria 1 initis in certain 1nsects. Tens. Acad. 8c1., 27 (3): 206. - 1953. Obeervations on the dsvelopment of Dirofilaria 1nerits in nosquitoes. Tenn. Acad. of Sel., 28 (3): 176.

Breind, A. 1921. Prellminary note on the developmont of the larvae of Dirol1laria 1 mitis in dog plas Ctenocephalldes relis and ean1s. Ann. Trop. Hed. E Parast., 14: 389-392.

Brown, H. W. 1939. Observation on the dog heartworm Dirofilaria 1 init1s. H. Anor. Vst., 20 (1): 40-55.

Burch, C. and K. E. Blalx. 1951. A rapld tsst for diagnosis or Dlrol1laria 1 imate1s. Vst. Ned., 46 (4): 128-130.

Connal, A. and 8. L. M. Connal. 1922. The development of Loa loa (Guyot) in Chrysops silaces (Austen) and Chrysops disldiata (van

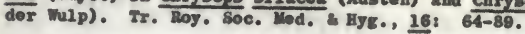

Del Rosario, F. 1936. Dirofilaria $1 \mathrm{~mm}$ tis and its eulleine intermadlate hosts in Manila, PhIlippine Islands. Philipplne Jour. Se1., 60: 45-55. 
Feng, L. C. 1930. Experiment with Dirofilaria 1 maitis and loesl species of mosquitoes in Polplag, North Chind, with a note on Lankesterla culicts lound in ledes korel cus. Ann. Trop. Med. I Parast tol., 24: 347-364.

Fox, I. 1840. Fleas of the Eastern Undted Btates. (Amos, Iowa, state college Prese), pp. 1-v11 + 191.

Grassi, B. 1888. Boträge zur kontniss des ontwi eklungeyclus von füne parasiton des huades. Contralb1. . Bakter. u. Barael tonk., IV: $609,776$.

Grassi, B. and S. Calandrucclo. 1890. Veber hasateroen Lowls. entwieklungscyelus einor Filaria (Fileris recondita Grassi) des hundes. Contralb1. 2. Bakter. u. Parast tenk, VII: 18.

Grassi, B. and G. Hoe. 1800. The propagetion of the l1larias of the blood exclusively by mans of the puncture of peculiax mequi toes. Brit. Med. Jour., 2: 1306-1307.

Gray, P. 1952. Handbook of basic aterotechnique. Philadelphia (Blakiston Co.), pp. 1-v111 + 141, 57 11Es.

Ha11, M. C., E. W. Priee and W. H. Wright. 1934. Paraeltes and barastic disenses of dogs. v. 8. Dopt. Asr. C1re. 338, p. 4.

H1 man, I. H. 1935. Experiantal studies on 111ar1el poriedielty. Jour. Trop. Mad. Eyt., 38 (21): 265-267.

- 1935. Studles on the dog heartworm, D1rol1larie 1 mit1s, Wth special reference to Illarial periodielty. Anr. Jour. Trop. Iod, , 15 (3): 371-383.

101.

HI nman, E. H. and D. D. Baker. 1936. Jour. Trop. Med., 39:

Hu, S. U. K. 1931. Studies on host-parasite relationshlpa of Dirofilarie 1 mitis Leidy and its eullel ne intermodiate hosts. Nuer. Jour. HyE., $15(3): 614-629,5 \mathrm{f1ge.}$

La Peyronnie, 1. 1778. (Quoted by sense 1778) Tr. de Malad Coeur., 2nd ed., vol. I: 241. soe., Ph1 1a.

Le1dy, J. 1856. 8ynopsis of Entozoa. Proe. Acad. Matural - 1881. Proc. Acad. Katural Soc., Ph1la.: 13. 
Lowis, T. R. 1875. On nomatode homatozon in the dog. Cuart. Jour. Merose, Soc., Now Serles, IV: 268.

Ianson, P. 1877. On F1larla sanguinolenta and Mlarla 10itis. (Report on Haenatozon). Custom Gazette.

Mognin, A. 1883. Hew. Sur les Hesatorosires du Chien. Jour. de I'Anat. et de la Physlolog1e: 172.

Honon, T. B. and B. Ranamurt1. 1941. The behav10r of the infective larvae of Whehererla bancroft1 with special reference to tholr mode of escape and penetration of skdn. Ind. Jour. Med. Mos., 29: 393-401, 3 f1gs.

Pasehot, J. 1679. Jour. des Savants. (Cuoted by Nounana, b. G. 1892) A treat1s on the parasites and parasit1c diseases of the domestlented animals. New York and London: 250.

Batton W. 8. 1913. A textbook of nedlcal entonology. London (Christian Lterature Soc. for India), pp. xv11 $+764,89$ pls. XI: 441.

Peyseon, A. 1806. Jour. de Lad, Chlr., Pharm, de Corvisart,

Phillips, J. H. 1939. Studies on the tranemession of Dirolllarla 1meltis in Massachusetts. Maer. Jour. Hyg., 29 (3): 121-129. Gasette: 680 .

Sehuppert, A. 1858. Now Orleans Mod. News and Hospltal

811va Aranje, R. 1878, Lyon lled1 eal, xxix: 319, 363.

Sonervl11e, J. 1875. Custons Gazette No. 7, shanghal.

Sumers, w. A. 1940. Floss as accoptable Intermodlate hosts of the dog heartworm pirolilaria imit1s. Proc. Soc. Exp. Blo. Hed., 43 (3): $\quad 48-450$.

nent of Drroftlo 1943. Experimental studion on the larval develop37 (3): $173-178$.

slifer, B. H. and R. L. King. 1933. serial sectioning of grasshopper egss. Sclence, 78: 366-367.

8onsino, P. 1888. Heerche sugll enatozol del cane. Att1 della Boc. Tose. di Se. Natura11, x. 
St1tt, B. B., P. W. Clough and M. C. Clough. 1945. Practieal bacterlology, heentology and alan parasitology. Philadelpha (BIakiston Co.), Pp. 1-xi11 $+961,208$ 11gs.

Underwood, P. C. and P. D. Harwood. 1939. Survival and location of the mierofilariae of Dirofilaria intile in the dog. Jour. Parasst. 25 (1): 23-33.

Yanada, S. 1927. An experimental study on tweaty-Pour opecles of Japanese nosquitoes regarding thelr musooptiblilty as Intermediate hosts for Fllarla bancroft1 Cobbold. Sc. Rep. Gov. Ingt. Inf. Dis., Tokyo Imp. Uni $\bar{\nabla}$, , 6: $559-622$.

Yen, C. H. 2938. Studies on Dirolilaria 1mitis Leldy with special reference to the susceptiblilty of som dilnnesota specles of mosquitees to the infection. Jour. Parasitol., 24 (3): 18s-205.

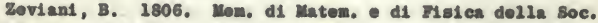
Itallani-Veron, XIV. 


\section{BJOCRAPEY}

Bdmand Bruno stuoben was born on Apr11 22, 1920, In Cuxhaven, Germany. Durlag the yeare from 1925 through 1933 he attended various elementary schools in Nev York and Cleveland, Ohio. In September 1937, he left Stujvesant Belence Mgh Behool of New York and entered Now York University. He anored in geology and recelved the degree Bachelor of Sclence In 1941. Upon completing college he joined the First Infantry Division of the Undted States Army. Following ternination of service in Oetober 1945 he Jolned the Bureau of Construction and Iater the Bureau of Plant Operation and Malntenance of the Bonrd of Bducation, Clty of Now York, as Assietant Wochandeal Bnglaeer. In September 1947 he entered Baylor Dniversity, Wace, Toxas, for additional course study in blology. The following year he began his graduate study in blology and was awarded the degree laster of Arts in Auguet 1949. In February 1950 he entered the University of Florida for graduate study in the fleld of blology. Durlng the period of September 1951 unt11 June 1953 he worked as a graduate aselstant in the Departient of Blology. He was awarded the degree Doctor of Puilosophy in August 1953. 
This dissertation was prepared under the direction of the Chairman of the candidate's Supervisory Comaltteo and has been approved by all members of the connate. It was submitted to the Dean of the College of Arts and sciences and to the Graduate council and was approved as partial fulfilment of the requirements for the degree of Doctor of Philosophy.

$$
\text { August 10, } 1953
$$
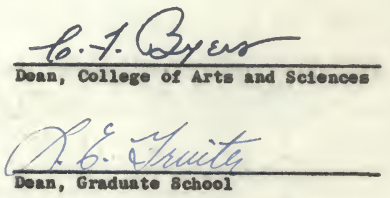

SUPERvIsoRY cosurTre:

cuss Burner

chaltran

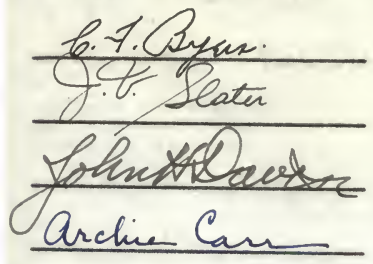


